\title{
Water relations and organic solutes production in four umbu tree (Spondias tuberosa) genotypes under intermittent drought
}

\section{Elizamar C. Silva ${ }^{1 *}$, Rejane J. M. C. Nogueira², Fernando H. A. Vale ${ }^{3}$, Natoniel F. de Melo ${ }^{4}$ and Francisco P. de Araújo ${ }^{4}$}

${ }^{1}$ Laboratório de Fisiologia Vegetal, Universidade Federal Rural de Pernambuco, 52171-030, Recife, PE, Brasil.

2 Departamento de Biologia, Universidade Federal Rural de Pernambuco, 52171-030, Recife, PE, Brasil.

${ }^{3}$ Instituto de Ciências Biológicas, Universidade Federal de Minas Gerais, MG, Brasil.

${ }^{4}$ Embrapa Semi-Árido, P. 0. Box 23, 56300-970, Petrolina, PE, Brasil.

* Part of the doctorate thesis of the first author. Corresponding author: elizaciriaco@gmail.com Received: 28 November 2008; Returned for revision: 24 July 2009; Accepted: 25 July 2009

In order to evaluate changes in leaf water potential $\left(\Psi_{\mathrm{w}}\right)$ and solute accumulation induced by intermittent drought, a research was performed under greenhouse conditions using four umbu tree genotypes (GBU 44, GBU 48, GBU 50 and GBU 68) and two water treatments (control and stressed by withholding water), with four replicates. The $\Psi_{w}$ was measured in four-hour intervals during a 24-hour period at the first stomatal closure and at the end of the experimental period. Carbohydrates, amino acids, protein and proline contents were also evaluated in leaves and roots. Significant differences were found in most of the studied parameters. The lower $\Psi_{\mathrm{w}}$ hour was between $800 \mathrm{~h}$ and $1200 \mathrm{~h}$. GBU 50 reduced significantly $\Psi_{\mathrm{w}}$ in stressed plants at $800 \mathrm{~h}$, while control plants reduced at $1200 \mathrm{~h}$. GBU 68 presented the higher $\Psi_{w}$. The extending of the stress induced reductions to carbohydrates in the leaves of all genotypes, increases in amino acids to GBU 44 and 48 , and reductions of $40 \%$ and $43 \%$ to GBU 50 and 68 , respectively; results also showed alterations in proline content. In the roots, increases in carbohydrates were observed only in GBU 48. Alterations in amino acids, protein, and proline were verified. Umbu trees presented isohydric behavior maintaining high leaf water potential and a great variability in organic solutes accumulation in response to drought with marked differences among the genotypes.

Key words: carbohydrates, proline, Spondias tuberosa, water potential

Relações hídricas e acúmulo de solutos orgânicos em quatro genótipos de umbuzeiro sob seca intermitente: Com o objetivo de avaliar as alterações no potencial hídrico foliar e 0 acúmulo de solutos compatíveis induzidos pela seca intermitente, foi desenvolvido um experimento em casa de vegetação utilizando-se quatro genótipos de umbuzeiro (GBU 44, GBU 48, GBU 50 e GBU 68) e dois regimes hídricos (controle e estresse com suspensão da irrigação), com quatro repetições. 0 potencial hídrico foliar ( $\left.\Psi_{\mathrm{w}}\right)$ foi medido em intervalos de quatro horas durante 24 horas no momento do primeiro fechamento estomático e no final do período experimental. Também foram avaliados os teores de carboidratos solúveis totais, aminoácidos, proteína e prolina nas folhas e nas raízes. Houve diferença significativa entre os acessos estudados para a maioria dos parâmetros avaliados. 0 horário de menor $\Psi_{\mathrm{w}}$ foi entre $8 \mathrm{~h}$ e $12 \mathrm{~h} .0 \Psi_{\mathrm{w}}$ das plantas estressadas do GBU 50 reduziu significativamente às 8h, enquanto que as plantas controle reduziram às $12 \mathrm{~h} .0$ acesso GBU 68 apresentou os valores mais elevados de $\Psi_{\text {w. }} 0$ prolongamento do estresse provocou reduções nos teores de carboidratos nas folhas de todos os acessos. Houve aumento no teor de aminoácidos nas folhas dos GBUs 44 e 48 e reduções de $40 \%$ e $43 \%$ para GBUs 50 e 68, respectivamente. Também foram observadas alterações nos teores de prolina. Nas raízes, houve aumento nos teores de carboidratos apenas no GBU 48. Foram verificadas alterações 
nos teores de aminoácidos, proteína e prolina. 0 umbuzeiro apresenta comportamento isoídrico, mantendo altos valores de potencial hídrico foliar e uma grande variação no acúmulo de solutos em resposta à seca, com marcada diferença genotípica.

Palavras-chave: carboidratos, potencial hídrico, prolina, Spondias tuberosa.

\section{INTRODUCTION}

Drought is a worldwide problem that adversely affects yield and crop quality (Chartzoulakis et al, 1999; Chartzoulakis et al., 2002; Souza et al., 2005; Hong-Bo et al, 2006). Reductions in the soil moisture as a result of withholding water lead straightly to changes in the plants physical environment, subsequently affecting physiological and biochemical processes (Sarker et al., 2005; Sircelj et al., 2005).

Plant drought-response is characterized by fundamental changes in the cell water relations (Pimentel, 2004). Reductions in cell volume as well as increments in solute accumulation and protoplasm dehydration are consequences of water deficiency (Nogueira et al, 2005). Thus, the measurement of leaf water potential is a reliable and evaluated way to express the water deficiency in tissue, particularly in leaves (Slatyer, 1967).

Some species can adapt to water deficiency by modifying the solute level inside the cells; thus, turgor, stomatal aperture, and physiological activities can be maintained under low leaf water potential (Chartzoulakis et al., 2002; Zhu et al., 2005; Bucci et al., 2008). This mechanism, known as osmotic adjustment, contributes to drought tolerance with desiccationavoidance and is defined as the ability to accumulate osmotically active solutes in response to drought (Quezada et al., 1999; Pagter et al., 2005, Farooq et al., 2009). However, the ability to accumulate osmotically active substances differs among species (Jones et al, 1980; Zhu et al., 2005).

It is well known that the osmotic regulators include many important molecules, e.g. potassium, soluble sugar, amino acids, proline and betaine. These molecules, which have low molecular weights, are important plant physiological indicators used to evaluate the ability to adjust osmotically and the drought-tolerance of many species and genotypes (Hong-Bo et al., 2006, Farooq et al., 2009). The main function of organic solutes is relative to protein stabilization, protein-complex and membranes when plants are submitted to environmental stresses (Bohnert and Shen, 1999).

Drought affects the metabolism of carbohydrates, which act as compatible solutes as much as antioxidant, increasing in response to water stress (Sircelj et al., 2005). However, Zhu et al. (2005) demonstrated in wheat that soluble sugar and inorganic ions contributed mainly to osmotic adjustment in the stage of seedling while proline and betaine accumulation had an important role in the subsequent stages, mostly as an osmoprotector when the soil was dry enough. Thus, plants response to drought can diverge within species and developmental stages.

Amino acids are another compound group affected by drought. The adaptable meaning concerning amino acids accumulation during stress period is still uncertain; however, a recent study indicates that amino acids principal function may be in osmotic adjustment (Sircelj et al., 2005).

Besides its contribution on osmotic adjustment, proline performs an important role in the membrane stabilization and free radical scavenging (Ashraf and Foolad, 2007; Farooq et al., 2009). A relationship between a higher proline accumulation and drought-tolerance has been found in plants or genotypes considered to be drought-tolerant (Quezada et al., 1999; Nogueira et al., 2001; Silva et al, 2004; Zhu et al., 2005).

The umbu tree (Spondias tuberosa Arruda) is a native species found in Brazilian dry lands (Caatinga), which shows a great phenotypic variation between its canopy and the weight of its fruits. Some genotypes produce fruits weighing $20 \mathrm{~g}$, while another ones can produce fruits weighing 120 g, called "giant umbu"(Santos et al., 1999). Among the 78 genotypes existent in the Active Germplasm Bank of Umbu Tree (GBU) located on the Brazilian Research Institute to the Semi Arid Tropic - Embrapa/CPATSA (Oliveira et al., 2004), the genotypes GBUs 44, 48, 50 and 68 are classified as giant umbu because the medium weight of the fruits of $86.7 \mathrm{~g}, 75.30$ g, $85.0 \mathrm{~g}$ and $96.7 \mathrm{~g}$, respectively (Santos et al. 1999).

Recent works of Lima Filho (2001, 2004), demonstrate that the water balance of umbu tree under drought conditions should be maintained through the utilization of the water storage in the roots (xylopodium) and a low transpiration rate. His results also showed that during the rainy season, water balance should be mediated by an osmotic adjustment. 
Literature containing physiological information about these genotypes is still scarce. Therfore, this work was carried out to test the hypothesis that the ability to overcome drought differs among genotypes and that this ability should be associated with leaf turgor maintaining by reducing water potential with the use of compatible solutes. The aim of this work was to evaluate alterations in leaf water potential and compatible solutes accumulation induced by intermittent drought in four umbu tree genotypes.

\section{MATERIAL AND METHODS}

Plant material, growth conditions and experimental design: The experiment was carried out in green house conditions from November to December 2005 at the Laboratório de Fisiologia Vegetal, belonging to the Department of Biology at the Universidade Federal Rural de Pernambuco. Four six-month-old grafting umbu genotypes (Spondias tuberose Arr. Cam.) produced by cleft graft were used. The plants were cultivated in pots containing $8 \mathrm{~kg}$ Acrisols soil (FAO) from CPATSA Petrolina, Pernambuco, Brazil. The physical properties were sandy-loam texture, composed of $71 \%$ sand, $17 \%$ clay and $12 \%$ silt and soil moisture at field capacity (0.3 atm) $9.97 \%$ and at the wilting point (15 atm) $4.01 \%$. The chemical soil analysis was done at the Laboratory of Soil Fertility of the Universidade Federal Rural de Pernambuco. The soil contained: $41 \mathrm{mg} / \mathrm{dm}^{3}$ of $P, 0.20 \mathrm{cmol}_{d}$ $\mathrm{dm}^{3}$ of $\mathrm{Na}^{+}, 0.33 \mathrm{cmol}_{d} / \mathrm{dm}^{3}$ of $\mathrm{K}^{+}, 7.15 \mathrm{cmol}_{d} / \mathrm{dm}_{\mathrm{m}}$ of $\mathrm{Ca}^{+2}+$ $\mathrm{Mg}^{+2}, 5.15 \mathrm{cmol}_{d} / \mathrm{dm}^{3}$ of $\mathrm{Ca}^{+2}$, and $0.05 \mathrm{cmol}_{d} / \mathrm{dm}^{3}$ of $\mathrm{Al}^{+3}$.

The experiment used a randomized experimental design, in a factorial $4 X 2$, corresponding to four umbu genotypes (GBU 44, GBU 48, GBU 50 and GBU 68) and two water treatments (control - watered daily until begin the free drainage, and stressed - by withholding water and re-watered when plants presented stomatal closure). Four replicates were performed.
The plant transpiration was measured daily between $900 \mathrm{~h}$ and $1000 \mathrm{~h}$ with a steady state porometer Li-1600 (LI-COR, Inc. Lincoln, NE, USA), to verify stomatal closure (data not showed). Climatic conditions during the experimental period are shown in Figure 1. The re-watering intervals-days of the stressed plants are found in Table 1.

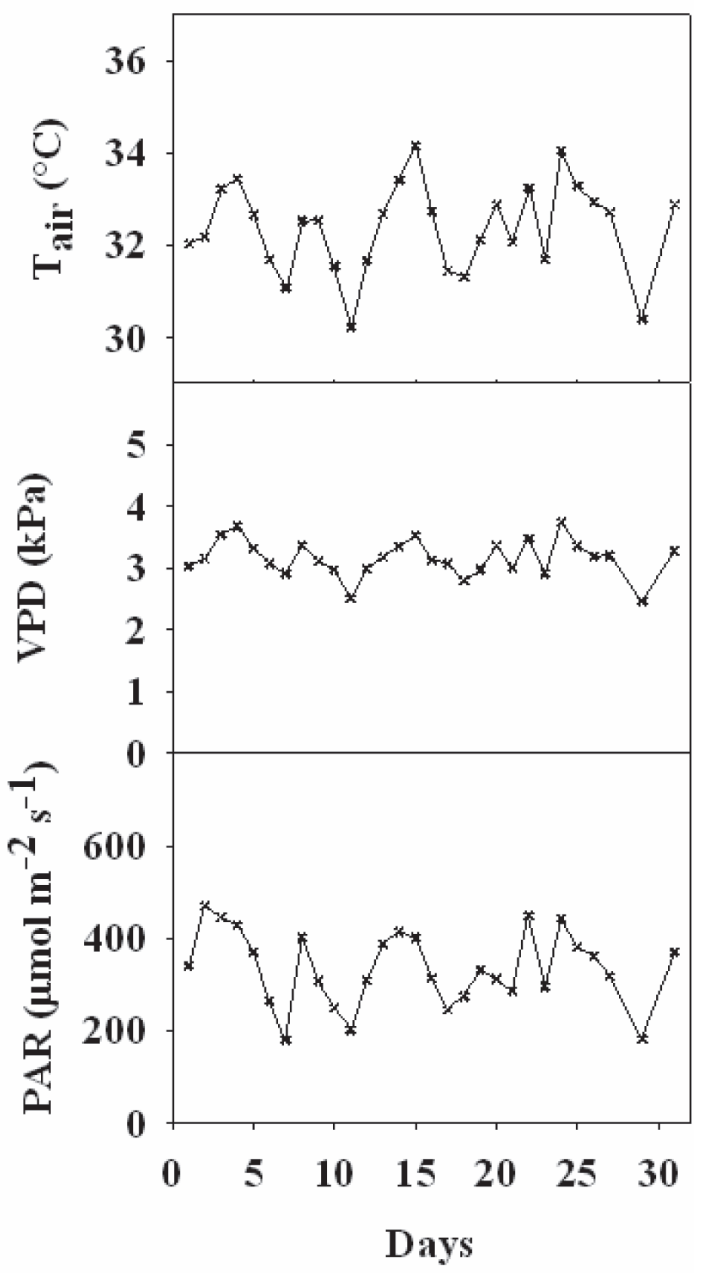

Figure 1. Air temperature ( $\left.\mathrm{T}_{\mathrm{air}}\right)$, vapor pressure deficit (VPD), and photosyntheticaly active radiation (PAR) taken daily during the experimental period, between $900 \mathrm{~h}$ and $1000 \mathrm{~h}$, in greenhouse conditions.

Table 1. Re-watering intervals (days) of four grafted umbu trees genotypes relative to stomatal closure.

\begin{tabular}{|c|c|c|c|c|c|c|}
\hline \multirow[b]{2}{*}{ Genotypes } & \multicolumn{6}{|c|}{ Watering days-intervals } \\
\hline & $\begin{array}{c}1^{\text {st }} \\
\text { watering }\end{array}$ & $\begin{array}{c}2^{\text {nd }} \\
\text { watering }\end{array}$ & $\begin{array}{c}3^{\text {rd }} \\
\text { watering }\end{array}$ & $\begin{array}{c}4^{\text {th }} \\
\text { watering }\end{array}$ & $\begin{array}{c}5^{\text {th }} \\
\text { watering }\end{array}$ & Mean \\
\hline GBU 44 & 5 & 6 & 5 & 5 & 5 & 5.2 \\
\hline GBU 48 & 5 & 7 & 7 & 5 & - & 6 \\
\hline GBU 50 & 5 & 8 & 7 & 6 & - & 6.5 \\
\hline GBU 68 & 4 & 5 & 6 & 5 & 4 & 4.8 \\
\hline
\end{tabular}


Leaf water potential measurement: When stressed plants presented the first stomatal closure, a time course of leaf water potential $\left(\Psi_{\mathrm{w}}\right)$ was accomplished using a pressure chamber model 3035 (Soil Moisture Equipment Corp, Santa Barbara, CA, USA) during 24-hours with four hours-intervals. Mature and full expanded leaves located above the medium part were sampled, wrapped in plastic film, and kept in a cold recipient. After harvesting, the measurements were performed in the laboratory of plant physiology. At the end of the experimental period, the same procedure was followed to measure $\Psi_{\mathrm{w}}$ again.

Soil moisture: After water potential measurements and before irrigation, soil samples were taken from three vases of each treatment and genotype for determining soil moisture, a total of 24 samples. The soil moisture was estimated according to equation: $\theta=$ (WSW -DSW)/DSW $\times 100$, where $\theta=$ soil moisture; $W S W=$ wet soil weight; $D S W=$ dry soil weight. Soil moisture characteristic curve was performed at the Laboratório de Física do Solo of the Universidade Federal Rural de Pernambuco, by Buchner Funnel method (Haines, 1930).

Biochemical analysis: The same leaves used to water potential measurements at $8 \mathrm{~h}$ were collected without the central vein and frozen to determine total soluble carbohydrates, free amino acids, soluble protein, and free proline. Likewise, sample of roots (xylopodium) were taken in the end of the experimental period. The extract was prepared by grinding about $2 \mathrm{~g}$ of fresh leaves and $5 \mathrm{~g}$ of fresh roots (xylopodium) with $4 \mathrm{~mL}$ (for leaves) and $10 \mathrm{~mL}$ (for roots) of sodium and potassium buffer $0.1 \mathrm{M}$ for 10 minutes. The homogenate was filtered in nylon mesh and centrifuged in a refrigerated centrifuge at 3,000 $\mathrm{xg}$ for 15 minutes and the supernatant was frozen to perform the analysis. Total soluble carbohydrates were determined for colorimetric technique $(490 \mathrm{~nm})$ by phenol-sulfuric acid, according to Dubois et al. (1956), using $\mathrm{D}(+)$-glucose as standard. Total free amino acid was determined by reaction with ninidrin $(570 \mathrm{~nm})$ using L-leucine as standard (Yemm and Cocking, 1955). For determining soluble protein content $(595 \mathrm{~nm})$ a protein-dye binding method was performed using bovine serum albumin as standard (Bradford, 1976). Free proline was determined by Bates et al (1973) method using a spectrophotometer in a wavelength of $520 \mathrm{~nm}$, ninidrin as specific reagent, and proline as standard.
Statistical analysis: Data were submitted to analysis of variance (ANOVA) and the means were compared by Tukey's multiple range test $(P<0.05)$.

\section{RESULTS}

During water-withholding period, the soil moisture decreased from $34.23 \%$ to $8.14 \%$ at the first stomatal closure (Table. 2), and from $30.7 \%$ to $3 \%$ after 31 days of treatment. This value is considered to be lower than permanent wilting point to this soil, which correspond to $4.0 \%(-1.5 \mathrm{MPa})$, as mentioned above in the material and method topic.

Table 2. Percent soil moisture on a weight basis of four umbu tree genotypes grown under intermittent drought. The first samples were taken before perform re-watering in stressed plants for occasion of the water potential measurements, when plants presented stomatal closure. The second sample collection corresponds to the last evaluation after 31 treatment days (harvest).

\begin{tabular}{ccccc}
\hline & \multicolumn{3}{c}{ Soil moisture (\%) } \\
\cline { 2 - 5 } & \multicolumn{2}{c}{$\mathbf{1}^{\text {st }}$. Sample } & \multicolumn{2}{c}{ 2d. Sample $^{\text {nd }}$. } \\
\cline { 2 - 5 } & \multicolumn{2}{c}{ Treatment } & \multicolumn{2}{c}{ Treatment } \\
\cline { 2 - 5 } & Control & Stressed & Control & Stressed \\
\hline GBU 44 & 15.76 & 5.76 & 17.35 & 1.89 \\
GBU 48 & 19.34 & 6.07 & 16.52 & 1.69 \\
GBU 50 & 18.69 & 8.98 & 17.37 & 2.31 \\
GBU 68 & 17.55 & 4.60 & 18.81 & 3.89 \\
\hline
\end{tabular}

Significant differences in leaf water potential $\left(\Psi_{\mathrm{w}}\right)$ were observed among genotypes $(P<0.01)$. GBU 68 showed the highest value of $\Psi_{\mathrm{w}}$ while GBU 50 showed the lowest. However, statistic analysis did not show significant differences between treatments (Table. 3).

Table 3. Daily average of leaf water potential $\left(\Psi_{\mathrm{w}}\right)$ of four umbu trees genotypes grown in greenhouse conditions under intermittent drought. Data was taken for occasion of the first stomatal closure and after 31 treatment days. The first stomatal closure occurred after four days of withholding water to genotype GBU 68 and after five days to GBU 44, 48 and 50.

\begin{tabular}{ccc}
\hline Genotype & $\begin{array}{c}\Psi_{\mathrm{w}}(\mathrm{MPa}) \\
\mathbf{1}^{\text {st }} \text { stomatal closure }\end{array}$ & $\begin{array}{c}\Psi_{\mathrm{w}}(\mathrm{MPa}) \\
\text { After } \mathbf{3 1} \text { treatment days }\end{array}$ \\
\hline GBU 44 & $-0.44 \mathrm{bA}$ & $-0.48 \mathrm{bA}$ \\
GBU 48 & $-0.37 \mathrm{bA}$ & $-0.33 \mathrm{aA}$ \\
GBU 50 & $-0.59 \mathrm{cA}$ & $-0.55 \mathrm{cA}$ \\
GBU 68 & $-0.27 \mathrm{aA}$ & $-0.34 \mathrm{aA}$ \\
\hline Treatments & & \\
\hline Control & $-0.40 \mathrm{aA}$ & $-0.38 \mathrm{aA}$ \\
Stressed & $-0.44 \mathrm{aA}$ & $-0.47 \mathrm{aA}$ \\
\hline
\end{tabular}

Values followed by different letters, lower case among treatments and among genotypes, and upper case between period, do not significantly differ according to the Tukey test $(P<0.05)$. 
In general, the time for lower $\Psi_{\mathrm{w}}$ was between $800 \mathrm{~h}$ and $1200 \mathrm{~h}$ for the most genotypes (Figure 2). Differences between treatments to GBU 44 and GBU 68 were not observed during 24-hour period when stressed plants presented the first stomatal closure.
The stressed plants of the GBU 48 reduced $\Psi_{w}$ at 800 h. However, there was no difference between treatments to the further hours. GBU 50 significantly reduced $\Psi_{\mathrm{w}}$ at $800 \mathrm{~h}$ $(P<0.01)$, recovering its $\Psi_{w}$ in the subsequent hours, while the control plants showed a $\Psi_{\mathrm{w}}$ reduction at $1200 \mathrm{~h}$ (Figure 2).

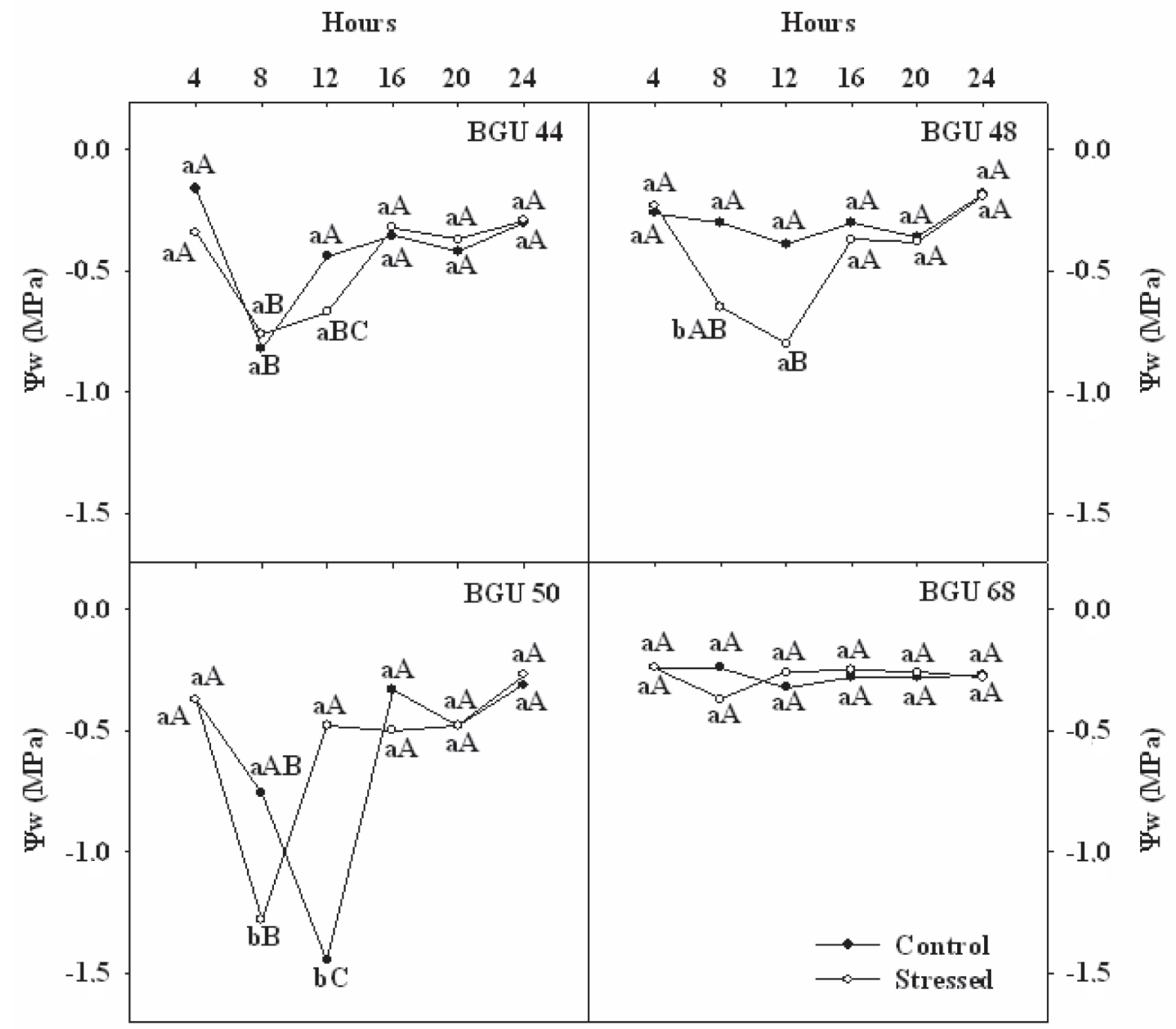

Figure 2. Daily course of leaf water potential $\left(\Psi_{\mathrm{w}}\right)$ of four umbu tree genotypes growing in green house conditions under intermittent drought by withholding water after four (genotype GBU 68) and five days (the remained genotypes). Values followed by different letters, lower case between treatments and upper case among hours, do not significantly differ according to the Tukey's test $(P<0.05)$.

A different behavior relative to leaf water potential was verified after 31 days in plants under intermittent drought. Genotypes GBU 44 and GBU 50 reduced significantly $\Psi_{w}$ at $800 \mathrm{~h}$ in comparison to control plants. This behavior was not observed in GBU 48 and GBU 68 (Figure 3). 


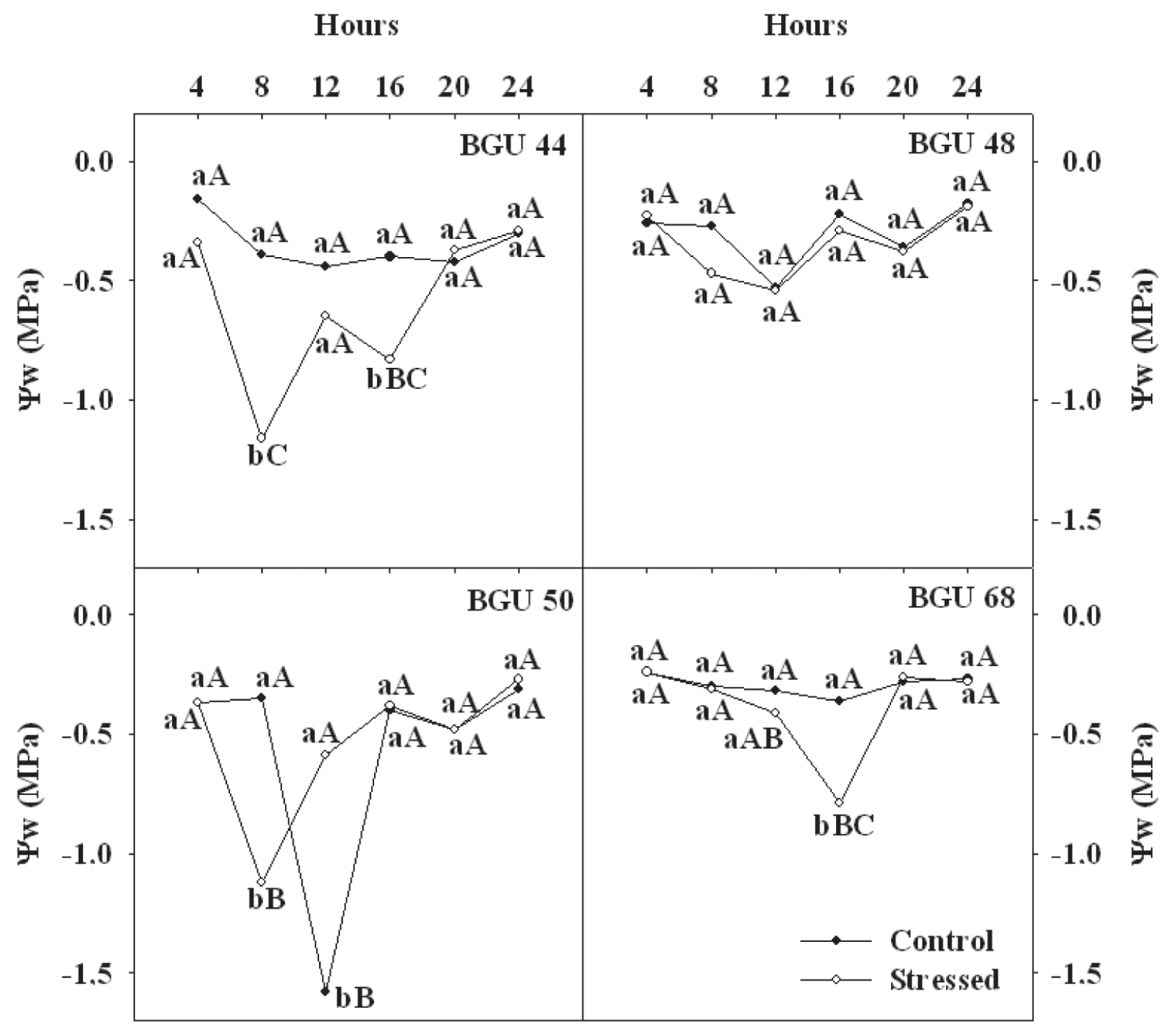

Figure 3. Daily course of leaf water potential $\left(\Psi_{\mathrm{w}}\right)$ of four umbu tree genotypes growing in green house conditions after 31 days under intermittent drought by withholding water. Plants were re-watered after the stomatal closure. Values followed by different letters, lower case between treatments and upper case among hours, do not significantly differ according to the Tukey's test $P<0.05$

In the hottest hour $(1200 \mathrm{~h})$ control plants of GBU 50 reduced $\Psi_{\mathrm{w}}$, while the stressed plants recovered $\Psi_{w}$, following the same pattern observed in the first evaluation (Figures 2 and 3). GBU 68 showed a different pattern again, waning $\Psi_{\text {w }}$ of the stressed plants at $1200 \mathrm{~h}$ culminating with the lower values at $1600 \mathrm{~h}$. Even though, the values of $\Psi_{w}$ in this genotype are still higher in comparison to the GBU 44 and 50 . Reductions in $\Psi_{\mathrm{w}}$ at $1600 \mathrm{~h}$ were also observed to $\mathrm{GBU} 44$, showing subsequent recovering.

The initial drought period induced reductions in the soluble carbohydrates content $(\mathrm{CH})$ only in genotype GBU 50 (Table 4). In times of sufficient water suppy, this genotype differed significantly from the others, showing the higher $\mathrm{CH}$ in the leaves. There were reductions in $\mathrm{CH}$ content with the drought cycle prolongation (Table 4). 
Table 4. Soluble carbohydrate contents in the leaves of four umbu tree genotypes growing under intermittent drought. The first harvest was done when the first stomatal closure occurred ( $4^{\text {th }}$ day to GBU 68 and $5^{\text {th }}$ day to the remained genotypes). The second harvest was performed after 31 days of treatments at $800 \mathrm{~h}$

\begin{tabular}{|c|c|c|c|c|}
\hline \multirow[b]{3}{*}{ Genotypes } & \multicolumn{4}{|c|}{ Carbohydrates $\left(\mu \mathrm{mol} \mathrm{gFW}^{-1}\right)$} \\
\hline & \multicolumn{2}{|c|}{$1^{\text {st }}$ harvest } & \multicolumn{2}{|c|}{$2^{\text {nd }}$ harvest } \\
\hline & Control & Stressed & Control & Stressed \\
\hline GBU 44 & $151.16 \mathrm{aB}$ & $127.00 \mathrm{aA}$ & $124.46 \mathrm{aA}$ & $94.84 \mathrm{bA}$ \\
\hline GBU 48 & $153.82 \mathrm{aB}$ & $136.10 \mathrm{aA}$ & $134.30 \mathrm{aA}$ & $87.33 \mathrm{bA}$ \\
\hline GBU 50 & $224.12 \mathrm{aA}$ & $126.65 \mathrm{bA}$ & $158.50 \mathrm{aA}$ & $95.85 \mathrm{bA}$ \\
\hline GBU 68 & $127.68 \mathrm{aB}$ & $144.52 \mathrm{aA}$ & $148.04 \mathrm{aA}$ & $99.50 \mathrm{bA}$ \\
\hline
\end{tabular}

Values followed by different letters, lower case among treatments and upper case among genotypes, do not significantly differ according to the Tukey test $(P<0.05)$.

There was a significant difference among genotypes concerning amino acid content $(A A)(P<0.01)$. The genotypes GBU 44 and 48 increased about $40 \%$ and $43 \%$ respectively in response to the initial reduction in the soil moisture while GBU 50 and 68 had reductions (Table 5). At the end of the experimental period the genotype GBU 44 still showed increases in the AA whereas GBU 50 showed reductions. The remaining genotypes did not show significant differences between treatments $(P<0.05)$ (Table 5).

Table 5. Free amino acids contents in the leaves of four umbu tree genotypes growing under intermittent drought. The first harvest was done when the first stomatal closure occurred ( $4^{\text {th }}$ day to GBU 68 and $5^{\text {th }}$ day to the remained genotypes) and the second harvest was performed after 31 days of treatments at $800 \mathrm{~h}$.

\begin{tabular}{|c|c|c|c|c|}
\hline \multirow[b]{3}{*}{ Genotypes } & \multicolumn{4}{|c|}{ Amino acids $\left(\mu \mathrm{mol} \mathrm{gFW}^{-1}\right)$} \\
\hline & \multicolumn{2}{|c|}{$1^{\text {st }}$ harvest } & \multicolumn{2}{|c|}{$2^{\text {nd }}$ harvest } \\
\hline & Control & Stressed & Control & Stressed \\
\hline GBU 44 & $6,84 \mathrm{bA}$ & $8,65 \mathrm{aA}$ & $5,13 \mathrm{bB}$ & $8,17 \mathrm{aA}$ \\
\hline GBU 48 & $6,86 \mathrm{bA}$ & $8,26 \mathrm{aA}$ & $6,97 \mathrm{aAB}$ & $7,92 \mathrm{aA}$ \\
\hline GBU 50 & $8,65 \mathrm{aA}$ & $5,20 \mathrm{bB}$ & $8,40 \mathrm{aA}$ & $5,65 \mathrm{bA}$ \\
\hline GBU 68 & $7,09 \mathrm{aA}$ & $4,00 \mathrm{bB}$ & $5,08 \mathrm{aB}$ & $6,09 \mathrm{aA}$ \\
\hline
\end{tabular}

Values followed by different letters, lower case among treatments and upper case among genotypes, do not significantly differ according to the Tukey test $(P<0.05)$.

There were no significant differences among genotypes and treatments concerning the protein content in the leaves (Table 6). There were no differences in praline among genotypes for plants grown in good soil water availability (Table 7). Among the genotypes, GBU 48 showed a significant increase of proline in the leaves at the first evaluation (72\%). The drought cycle prolongation induced accumulation of proline in the leaves in the most stressed plants, except to GBU 50 (Table 7). There were increases of $52 \%, 49.3 \%$ and $49.4 \%$ to GBU 44,48 and 68 , respectively.

Table 6. Total soluble protein content in leaves of four umbu tree genotypes growing under intermittent drought. The first harvest was done when the first stomatal closure occurred ( $4^{\text {th }}$ day to GBU 68 and $5^{\text {th }}$ day to the remained genotypes) and the second harvest was performed after 31 days of treatments at $800 \mathrm{~h}$.

\begin{tabular}{|c|c|c|c|c|}
\hline \multirow[b]{3}{*}{ Genotypes } & \multicolumn{4}{|c|}{ Protein $\left(\mu \mathrm{mol} \mathrm{gFW}^{-1}\right)$} \\
\hline & \multicolumn{2}{|c|}{$1^{\text {st }}$ harvest } & \multicolumn{2}{|c|}{$2^{\text {nd }}$ harvest } \\
\hline & Control & Stressed & Control & Stressed \\
\hline GBU 44 & $163.38 \mathrm{aA}$ & $216.91 \mathrm{aA}$ & $77.04 \mathrm{aA}$ & $88.32 \mathrm{aA}$ \\
\hline GBU 48 & $158.00 \mathrm{aA}$ & $171.91 \mathrm{aA}$ & $76.25 \mathrm{aA}$ & $82.03 \mathrm{aA}$ \\
\hline GBU 50 & $231.26 \mathrm{aA}$ & $259.41 \mathrm{aA}$ & $117.86 \mathrm{aA}$ & $109.99 \mathrm{aA}$ \\
\hline GBU 68 & $145.06 \mathrm{aA}$ & $121.55 \mathrm{aA}$ & $76.37 \mathrm{aA}$ & $85.04 \mathrm{aA}$ \\
\hline
\end{tabular}

Values followed by different letters, lower case among treatments and upper case among genotypes do not significantly differ according to the Tukey test $(P<0.05)$. 
Table 7. Free proline content in leaves of four umbu tree genotypes growing under intermittent drought. The first harvest was done when the first stomatal closure occurred ( $4^{\text {th }}$ day to GBU 68 and $5^{\text {th }}$ day to the remained genotypes) and the second harvest was performed after 31 days of treatments at $800 \mathrm{~h}$.

\begin{tabular}{|c|c|c|c|c|}
\hline \multirow[b]{3}{*}{ Genotypes } & \multicolumn{4}{|c|}{ Proline $\left(\mu \mathrm{mol} \mathrm{gFW}^{-1}\right)$} \\
\hline & \multicolumn{2}{|c|}{$1^{\text {st }}$ harvest } & \multicolumn{2}{|c|}{$2^{\text {nd }}$ harvest } \\
\hline & Control & Stressed & Control & Stressed \\
\hline GBU 44 & $12.09 \mathrm{aA}$ & $10.61 \mathrm{aB}$ & $5.44 \mathrm{bA}$ & $8.54 \mathrm{aA}$ \\
\hline GBU 48 & $12.86 \mathrm{bA}$ & $22.38 \mathrm{aA}$ & $4.97 \mathrm{bA}$ & $7.74 \mathrm{aAB}$ \\
\hline GBU 50 & $11.23 \mathrm{aA}$ & $10.44 \mathrm{aB}$ & $5.44 \mathrm{aA}$ & $6.01 \mathrm{aB}$ \\
\hline GBU 68 & $6.86 \mathrm{aA}$ & $5,59 \mathrm{aB}$ & $5.99 \mathrm{bA}$ & $9.15 \mathrm{aA}$ \\
\hline
\end{tabular}

Values followed by different letters, lower case among treatments and upper case among genotypes, do not significantly differ according to the Tukey test $(P<0.05)$.

The organic solutes accumulation in the roots did not follow the same pattern found in the leaves. The intermittent drought induced increases in the carbohydrate content in the roots only to genotype GBU 48 (Table 8). Contrary, there were reductions in $\mathrm{CH}$ to $\mathrm{GBU} 68$. This last genotype was the only one that showed the higher AA in response to stress, increasing 2.5 -fold in comparison to the control. The remained genotypes stayed unchanged.

Table 8. Total soluble carbohydrates, free amino acids, total soluble protein and free proline contents in the roots (xylopodium) of four umbu tree genotypes under intermittent drought after 31 treatment days.

\begin{tabular}{|c|c|c|}
\hline Genotypes & Control & Stress \\
\hline \multicolumn{3}{|c|}{ Carbohydrates $\left(\mu \mathrm{mol} \mathrm{gFW}^{-1}\right)$} \\
\hline GBU 44 & $126.72 \mathrm{aAB}$ & $128.65 \mathrm{aA}$ \\
\hline GBU 48 & $118.71 \mathrm{bB}$ & $127.84 \mathrm{aA}$ \\
\hline GBU 50 & $123.4 \mathrm{aAB}$ & $122.89 \mathrm{aA}$ \\
\hline GBU 68 & $132.85 \mathrm{aA}$ & $108.09 \mathrm{bB}$ \\
\hline \multicolumn{3}{|c|}{ Amino acids $\left(\mu \mathrm{mol}_{\mathrm{g}} \mathrm{gFW}^{-1}\right)$} \\
\hline GBU 44 & $1.03 \mathrm{aA}$ & $1.81 \mathrm{aAB}$ \\
\hline GBU 48 & $1.76 \mathrm{aA}$ & $1.31 \mathrm{aAB}$ \\
\hline GBU 50 & $1.10 \mathrm{aA}$ & $1.20 \mathrm{aB}$ \\
\hline GBU 68 & $0.97 \mathrm{bA}$ & $2.39 \mathrm{aA}$ \\
\hline \multicolumn{3}{|c|}{ Protein $\left(\mu\right.$ mol.gFM $\left.^{-1}\right)$} \\
\hline GBU 44 & 54.31 bA & $66.41 \mathrm{aA}$ \\
\hline GBU 48 & $52.81 \mathrm{aA}$ & $60.59 \mathrm{aAB}$ \\
\hline GBU 50 & $57.84 \mathrm{aA}$ & $48.29 \mathrm{bB}$ \\
\hline GBU 68 & $52.46 \mathrm{aA}$ & $35.68 \mathrm{bC}$ \\
\hline \multicolumn{3}{|c|}{ Proline $\left(\mu \mathrm{mol}_{\mathrm{gFW}}{ }^{-1}\right)$} \\
\hline GBU 44 & $0.85 \mathrm{aB}$ & $1.11 \mathrm{aB}$ \\
\hline GBU 48 & $2.10 \mathrm{aA}$ & $1.54 \mathrm{aB}$ \\
\hline GBU 50 & $0.88 \mathrm{bB}$ & $1.43 \mathrm{aB}$ \\
\hline GBU 68 & 1.14 bAB & $3.49 \mathrm{aA}$ \\
\hline
\end{tabular}

Values followed by different letters, lower case among treatments and upper case among genotypes do not significantly differ according to the Tukey test $(P<0.05)$.
There were increases in the protein content in the roots of stressed plants to GBU 44 (Table 8). The genotype GBU 48 remained unchanged, whereas the genotypes GBU 50 and 68 reduced protein content.

Proline content in the roots (xylopodium) differs significantly among genotypes GBU 48 and GBU 44 and 50 under control conditions (Table 8). Under stress conditions, the genotype GBU 68 showed the higher proline content in the roots in comparison to control plants. Stressed plants of GBU 68 increased the proline content in response to drought about threefold more the than control plants.

\section{DISCUSSION}

Field observations accomplished by Lima Filho (2001) demonstrated that the lowest $\Psi_{\mathrm{w}}$ in umbu tree was at 800 h $(-0.97 \mathrm{MPa})$ during dry season, corroborating the data generated for this study. However, the author did not observe $\Psi_{\mathrm{w}}$ recovering during the daytime, which differs from the results of this study (Figures 2 and 3 ). This difference could be attributed to the cultivation conditions. In field-grown plants, the environmental factors, i.e. radiation, vapor pressure deficit, and the speed of the wind, exert a bigger impact on the plants, compared to greenhouse conditions. In this last case, the smaller volume of the soil to be explored also may become a stress factor.

Some authors have reported that the measurement of pre-dawn leaf water potential $\left(\Psi_{\mathrm{pd}}\right)$ is more sensitive than other evaluation hours, because it does estimate the maximum value of water potential on the root zone, and it is not dependent of the short-term climatic changes (Améglio et al., 1999; Sircelj et al., 2005). If pre-dawn transpiration does 
not occur, the water potential gradient on the plant disappears, and the $\Psi_{\mathrm{pd}}$ can be taken to represent the water potential in the soil explored by the roots (Améglio et al., 1999). In response of water deficit in two eucalyptus species and in three woody native species of Ethiopia, it could be observed, that the difference between $\Psi_{\text {pd }}$ values in plants cultivated under 25\% of field capacity (FC) and the control (100\% FC) was around 1.0 MPa (Gindaba et al., 2005).

The fact that umbu plants still showed high leaf water potential, even with soil moisture below $4 \%$, which is equivalent to $-15 \mathrm{kPa}$ (Table 1), supports the hypothesis that the water stored in the xylopodium, combined with stomatal closure (Lima Filho, 2001, 2004), is responsible for maintaining the water status as the first defense line against desiccation in this species. The higher $\Psi_{\text {pd }}$ with lower soil moisture content suggest that the measurements of $\Psi_{\text {pd }}$ is not appropriate to estimate soil water potential in umbu plants and probably to other plant species with similar root system architecture.

The water loss by transpiration in the higher evaporative demand hour may cause reductions on the leaf water potential and the reductions are apparent even in plants grown under good water conditions, since the leaf water potential results in the interaction of the atmospheric evaporative demand with the soil water potential (Silva et al., 2003). Thus, the roots absorb less water than it looses to the atmosphere, because the water is passively moved throughout the roots in response to water potential gradient created by transpiration (Steudle and Peterson, 1998). This transient water deficit on the higher transpiration demand hour could explain the temporary $\Psi \mathrm{W}$ reductions at midday in control plants of the genotype GBU 50 (Figures 2 and 3).

Reductions on leaf water potential at midday in wellirrigated plants were found in two eucalyptus species, with value of $\Psi_{\text {pd }}$ around $-0.4 \mathrm{MPa}$ and of $-0.8 \mathrm{MPa}$ at midday. However, the difference between $\Psi_{w}$ at midday in well irrigated plants and those under severe stress (25\% FC) was of $1.4 \mathrm{MPa}$ to Eucalyptus globules and of $1.14 \mathrm{MPa}$ to $\mathrm{E}$. camaldulensis (Gindaba et al., 2005).

The high values of $\Psi_{w}$ found in umbu plants with little variations during the day and between treatments suggest that this specie has isohydric behavior (Tardieu and Simonneau, 1998; Frank et al., 2007), because its rigid stomatal control reduced the transpiration at midday (Lima Filho, 2004, Nogueira et al., 2008). According to Lima Filho (2004) the umbu tree exhibits two peaks of transpiration (at $800 \mathrm{~h}$ and $1400 \mathrm{~h}$ ) in the field. This information should support the behavior of the genotypes GBU 50 and GBU 68, which reduced the $\Psi_{\mathrm{w}}$ at 800 $h$ and $1400 \mathrm{~h}$, respectively (Figure 3).

Solute accumulation in response to drought is important for maintaining cell turgor by reducing water potential (Farooq et al., 2009) and certainly there are several organic solutes participating in this process as sugars, amino acids, soluble proteins, proline, betaine and others soluble solutes of low molecular weight. In the present work it was verified, if there is a variation in the pattern of accumulation of solutes among genotypes in response to water stress.

Sircelj et al (2005) observed significant increases of carbohydrates, mainly on sorbitol content in apple tree cultivated after 10, 15 and 20 days of withholding water (which is considered a moderate stress treatment). However, at 23 days of treatment (which may represents a severe stress), a decreasing in the sorbitol contents was observed in $22 \%$ and $23 \%$ of the two studied cultivars, suggesting depletion in the sorbitol levels when plants were submitted to severe stress. Nevertheless, in the present work, variations in carbohydrates content among genotypes were observed in leaves in response to drought and to the time of evaluation, reducing to GBU 50 at the first sign of soil drying and after 31 days in all genotypes studied (Table 4). The reductions in soluble carbohydrates content in umbu plants under stress suggest depletion or translocation to the roots, which should be important to maintain water absorption.

Free amino acids contribute also to osmotic adjustment and this has been observed in the plants submitted to water deficit (Rabe, 1990; Sircelj et al., 2005). Alterations in amino acids content were verified in two apple tree cultivars under severe water deficit, increasing more than $40 \%$ in comparison with the control plants (Sircelj et al., 2005). In this present work it was verified, with variation in amino acids content among genotypes, where some genotypes responded to a short period of drought, increasing in GBU 44 and 48 and reducing in genotypes GBU 50 and 68. Genotypic variations were observed also with a prolonged stress period (Table 5).

Nevertheless, no variations were observed between treatments in protein content (Table 6), indicating that there was no proteolysis in response to drought cycles imposed 
during the stress period. These results suggest that the increases in the amino acid content to genotypes GBU 44 and 48 occurred through synthesis and not because of a protein degradation in response to drought.

Proline is broadly found in higher plants and it often accumulates in response to environmental stresses (Ashraf and Foolad, 2007). A significant increase in proline content was reported in leaves of zarzamora (Rubus spp.) when plants were submitted to withholding of water (Quezada et al., 1999). The authors observed two-folds more proline in stressed plants $\left(1.81 \mathrm{mg} . \mathrm{g}^{-1} \mathrm{MS}\right)$ than in plants of a control group (0.83 mg. $\left.\mathrm{g}^{-1} \mathrm{MS}\right)$. Nogueira et al. (2001) found high values of proline in stressed plants by withholding water of Surinam cherry until 38-folds than in daily-irrigated plants.

The present work showed increases in proline content in almost all genotypes after 31days. Short-term, just genotype GBU 48 responded to stress increasing proline in the leaves (Table 7). Besides of its role in osmoregulation, proline contributes to membrane stabilization and free radicals scavenging (Asharaf and Foolad, 2007).

Similar to the leaves, no trends in carbohydrate content was found in roots in response to drought, since there was an increase in GBU 48 and a decrease in GBU68, while the remaining genotypes did not present alterations. In response to drought, just GBU 68 accumulates both amino acids and proline in the roots. However, this could be explained by proteolysis (Table 8). Proteolysis also occurred in the roots of GBU 50, but this genotype did not show increases in amino acids content, but in proline content.

As roots are in contact with the soil, they are the first organs suffering from the impacts of the soil moisture changes. Thus, the accumulation of active organic solutes is important for maintaining the water inflow inside the cells and the transport to the shoot.

According to results of Taiz and Zeiger (2004), the osmotic adjustment develops slowly in response to the tissue dehydration. Leaves capable to perform osmotic adjustment can maintain their turgor more effectively under lower water potential than the ones without this capacity. The turgor maintenance enables the continuity of cell elongation and facilitates higher stomatal conductance under lower water potential, suggesting that the osmotic adjustment is a type of acclimatization, which increases the tolerance to dehydration.
Certainly, the substances accumulated during the stress period did not contribute to maintain the turgor in all umbu tree genotypes, which is the case of proline in the leaves of most genotypes studied and in the roots of the GBU 68. However, in quantitative terms, the values of proline content are not too representative when compared with carbohydrates, which represent about $50 \%$ of the total osmotically active solutes in plants (Ashraf and Harris, 2004), and this solute was reduced in response to water stress. Thus, in the growth conditions of the present work, accumulation of solutes was not evident in umbu plants as an indicator for drought-tolerance.

\section{CONCLUSIONS}

Summarizing, umbu trees presented isohydric behavior during intermittent drought maintaining high leaf water potential and a great variability in the production of organic solutes with marked differences among the genotypes. The high values of water potential and the variability in the organic solutes studied suggest that the storage of water in the xylopodium associated with the stomatal closure is the cause of maintaining turgor in the leaves of umbu tree genotypes and that solute accumulation was not evident in umbu plants as a drought-tolerance indicator.

Acknowledgment: The authors would like to thank the Coordenação de Aperfeiçoamento de Pessoal de Nível Superior (CAPES) for financial support, Dr. Júlio Villar and Anacleto Junior from the Laboratório de Física do Solo for soil analysis, and Michael Kalani Kauwe for English language corrections.

\section{REFERENCES}

Améglio T, Archer P, Cohen M, Valancogne C, Daudet FA, Dayau S, Cruiziat P (1999) Significance and limits in the use of predawn leaf water potential for tree irrigation. Plant Soil. 207:155-167.

Ashraf M, Harris PJC (2004) Potential biochemical indicators of salinity tolerance in plants. Plant Sci. 166: 3-16.

Ashraf M, Foolad M R (2007) Roles of glycine betaine and proline in improving plant abiotic stress resistance. Environ. Exp. Bot. 59:206-216.

Bates LS, Waldren RP, Teare ID (1973) Rapid determination of free proline for water-stress studies. Plant Soil. 39:205-207.

Bohnert HJ, Shen B (1999) Transformation and compatible solutes. Sci. Hort. 78:237-260. 
Bradford MM (1976) A rapid and sensitive method for the quantification of microgram quantities of protein utilizing the principles of protein-dye binding. Anal. Biochem. 72:246-254.

Bucci SJ, Scholz FG, Goldstein G, Meinzer FC, Franco AC, Zhang Y, Hao GY (2008) Water relations and hydraulic architecture in Cerrado trees: adjustments to seasonal changes in water availability and evaporative demand. Braz. J. Plant Physiol. 20:233-245.

Chartzoulakis K, Patakas A, Bosabalidis AM (1999) Changes in water relations, photosynthesis and leaf anatomy induced by intermittent drought in two olive cultivars. Environ. Exp. Bot. 42:113-120

Charzoulakis K, Patakas A, Kofidis G, Bosabalidis A, Nastou A (2002) Water stress affects leaf anatomy, gas exchange, water relations and growth of two avocado cultivars. Sci. Hort. 95:39-50.

Dubois M, Gilles KA, Hamilton JK, Rebers PA, Smith F (1956) Colorimetric method for determination of sugars and related substances. Anal. Chem. 28:350-356.

Farooq M, Wahid A, Kobayashi N, Fujita D, Basra SMA (2009) Plant drought stress: effects, mechanisms and management. Agron. Sustain. Dev. 29:185-212.

Frank PJ, Drake PL, Froend RH (2007) Anisohydric but isohydrodynamic: seasonally constant plant water potential gradient explained by a stomatal control mechanism incorporating variable plant hydraulic conductance. Plant Cell Environm. 30:19-30.

Gindaba J, Rozanov A, Negash L (2005) Photosynthetic gas exchange, growth and biomass allocation of two Eucalyptus and three indigenous tree species of Ethiopia under moisture deficit. Forest Ecol. Manag. 205:127-138.

Haines WB (1930) Studies in the physical properties of soil. V. The hysteresis effect in capillary properties, and the modes of moisture distribution associated therewith. J. Agric. Sci. 10:96-105.

Hong-Bo F, Xiao-Yan C, Li-Ye C., Xi-Ling Z., Gang W, Yong-Bing Y, Chang-Xing Z, Zan-Min H. (2006) Investigation on the relationship of proline with wheat anti-drought under soil water deficits. Coll. Surf. B. 53:113-119.

Jones MM., Osmond CB, Turner NC (1980) Accumulation of solutes in leaves of sorghum and sunflower in response to water deficit. Aust. J. Plant Physiol. 7:193-205

Lima Filho JMP (2001) Internal water relations of the umbu tree under semiarid conditions. Rev. Bras. Frutic. 23:518-521.

Lima Filho JMP (2004) Gas exchange of the umbu tree under semi-arid conditions. Rev. Bras. Frutic. 26:206-208.

Nogueira RJMC, Moraes JAPM, Burity HA, Bezerra Neto E (2001) Alterações na resistência à difusão de vapor das folhas e relações hídricas em aceroleiras submetidas a déficit de água. Rev. Bras. Fisiol. Veg. 13:75-87.

Nogueira RJMC, Albuquerque MB, Silva EC (2005) Aspectos ecofisiológicos da tolerância à seca em plantas da caatinga. In: Nogueira RJMC, Araújo EL, Willadino LG, Cavalcante UMT (eds), Estresses ambientais: danos e benefícios em plantas, pp 22-31, Imprensa Universitária da UFRPE, Recife, Brasil.

Nogueira RJMC, Silva EC, Sousa EB, Silva MAV, Silva MA, Martins M0 (2008) Variabilidade do grau de tolerância à seca em fruteiras tropicais cultivadas no Nordeste. In: Moura NA, Araújo EL, Albuquerque UP (eds), Biodiversidade, potencial econômico e processos ecofisiológicos em ecossistemas nordestinos, pp 302-328, Comunigraf, Recife, Brasil..

Oliveira VR, Resende MEV, Nascimento CES, Drumond MA, Santos CAF (2004) Genetic variability of provenances and progenies of umbu tree by mixed linear model methodology (REML/BLUP). Rev. Bras. Frutic. 26: 53-56.

Pagter M, Bragato C, Brix H (2005) Tolerance and physiological responses of Phragmites australis to water stress. Aquatic Bot. 81:285-299.

Pimentel C (2004) A Relação da Planta com a Água. Seropédica, Rio de Janeiro.

Quezada RAP, Ontiveros JLR, Hernández VAG (1999) Transpiracion, potencial hídrico y prolina em zarzamora bajo déficit hídrico. Terra. 17:125-130.

Rabe E (1990) Stress physiology: the functional significance of the accumulation of nitrogen-containing compounds. J. Hortic. Sci. 65:231-243.

Santos CAF, Nascimento CES, Oliveira MC (1999) Recursos genéticos do umbuzeiro: preservação, utilização e abordagem metodológica. In: Queiróz MA, Goedert C0, Ramos SRR (eds). Recursos genéticos e melhoramento de plantas do Nordeste brasileiro (on-line). Versão 1.0. Petrolina-PE. EMBRAPA Semi-Árido/Brasília-DF: Embrapa Recursos Genéticos e Biotecnologia. Nov, 1999. Disponível em: http://www.cpatsa.embrapa.br/livrorg/umbuzeiro.doc. Acesso em 24 ago. 2003.

Sarker BC, Hara M, Uemura M (2005) Proline synthesis, physiologica responses and biomass yield of eggplants during and after repetitive soil moisture stress. Sci. Hort.103:387-402.

SilvaEC, Nogueira RJMC, Azevedo Neto AD, Santos VF (2003) Comportamento estomático e potencial da água da folha em três espécies lenhosas cultivadas sob estresse hídrico. Acta Bot. Bras. 17:231-246.

Silva EC, Nogueira RJMC, Azevedo Neto AD, Brito JZ, Cabral EL (2004) Aspectos ecofisiológicos de dez espécies em uma área de caatinga no município de Cabaceiras, Paraíba, Brasil. Iheringia, Sér. Bot. 59:201-205

Sircelj H, Tausz M, Grill D, Batic F (2005) Biochemical responses in leaves of two apple tree cultivars subjected to progressing drought. J. Plant Physiol. 162:1308-1318.

Slatyer R0 (1967) Plant-water relationships, Academic, New York.

Souza CR, Maroco, JP, Santos TP, Rodríguez ML, Lopes, C, Pereira JS, Chaves, MM (2005) Control of stomatal aperture and carbon uptake by deficit irrigation in two gravepines cultivars. Agricult. Ecosys. Environ. 106:261-274.

Steudle E, Peterson CA (1998) How does water get through roots? J. Exp. Bot. 49:775-788.

Taiz L, Zeiger E (2004) Plant Physiology, 3rd ed. Sinauer Associates Inc., Massachusetts.

Tardieu F, Simonneau T (1998) Variability among species of stomatal control under fluctuating soil water status and evaporative demand: modelling isohydric and anisohydric behaviours. J. Exp. Bot. 49:419-432.

Yemm EW, Cocking EC (1955) Determination of amino acids with ninhydrin. Analyst, 80:209-213.

Zhu X, Gong H, Chen G, Wang S, Zhang C (2005) Different solute levels in two spring wheat cultivars induced by progressive field water stress at different developmental stages. J. Arid Environ. 62:1-14. 